\title{
Pola Asuh Orang Tua dalam Mencegah Perilaku Pergaulan Bebas Remaja Desa Krueng Geukuh Kecamatan Dewantara
}

\author{
Arini Agustina ${ }^{1}$, Idawati $^{2}$ \\ ${ }^{1}$ Mahasiswa Gizi Kesehatan Keluarga Kespro S2 IKM Institut Kesehatan Helvetia, Medan \\ ${ }^{2}$ STIKes Medika Nurul Islam Sigli \\ Email : aryniagustina@gmail.com \\ Email : idawati.medika@gmail.com \\ DOI : $10.32672 /$ jsa.v7i5.1525
}

\begin{abstract}
Free association is a double burden for the country of Indonesia because it can cause high sexually transmitted diseases. Aceh has been enveloped by the atmosphere of promiscuity at a very severe stage. A preliminary study conducted in Para Tujuh Hamlet, Krueng Geukuh Village, Dewantara sub-district, found that there was a case of a high school teenager who had a pregnancy outside of marriage. This study aims to determine the effect of knowledge, attitudes, local wisdom, social media, and peers on parenting in preventing promiscuity in adolescents in Krueng Geukuh Village, Dewantara Subdistrict in 2018. This type of research is a quantitative survey conducted analytical with cross sectional approach. Population of 121 people. Samples aged 14-18 years as many as 93 people. The results showed that there was a relationship between knowledge, attitudes, local wisdom, peers on promiscuity and no social media relations, family / parenting style for free association and more dominant attitude variables affecting promiscuity with Exp (B) values higher than on other variables. The results of multiple logistic regression with Overall value $=73.1 \%$. It is expected that adolescents will fortify themselves from the effects of free association such as holding back the desire to do negative things, fulfilling their busy life with positive things and increasing knowledge about religion.
\end{abstract}

\section{Keywords : Parenting Parenting, Free Intercourse Behavior, Youth}

\begin{abstract}
ABSTRAK.
Pergaulan bebas menjadi beban ganda bagi negara indonesia karena bisa menyebabkan tingginya penyakit menular seksual. Aceh sudah di selimuti oleh atmosfer perilaku pergaulan bebas pada stadium tingkat yang sudah sangat parah. Studi pendahuluan yang dilakukan di Dusun Para Tujuh Desa Krueng Geukuh kecamatan Dewantara didapatkan adanya kasus salah seorang remaja SMA yang mengalami kehamilan diluar nikah. Penelitian ini bertujuan untuk mengetahui pengaruh pengetahuan, sikap, kearifan lokal, sosial media, dan teman sebaya terhadap pola asuh orang tua dalam mencegah perilaku pergaulan bebas pada remaja di Desa Krueng Geukuh Kecamatan Dewantara tahun 2018. Jenis penelitian ini merupakan penelitian kuantitatif yang dilakukan secara survey analitik dengan pendekatan cros sectional. Populasi 121 orang. Sampel berusia 14-18 tahun
\end{abstract}


Arini Agustina, Idawati

sebanyak 93 orang. Hasil penelitian menunjukkan bahwa ada hubungan pengetahuan, sikap, kearifan lokal, teman sebaya terhadap pergaulan bebas dan tidak ada hubungan sosial media, keluarga/pola asuh terhadap pergaulan bebas serta variabel sikap lebih dominan memengaruhi pergaulan bebas dengan Overall percentage $=73,1 \%$. Diharapkan kepada remaja agar membentengi diri dari dampak pergaulan bebas seperti menahan hasrat untuk melakukan hal-hal yang negatif, memenuhi kesibukan diri dengan hal-hal yang positif dan meningkatkan ilmu tentang agama.

\section{Kata kunci : Pola Asuh Orang Tua, Perilaku Pergaulan Bebas, Remaja}

\section{PENDAHULUAN}

Remaja dan Seks bebas ibarat gunung es yang hanya terlihat sedikit, namun pada faktanya mayoritas generasi di Indonesia tak terkecuali Aceh sudah di selimuti oleh atmosfer perilaku seks bebas pada stadium tingkat yang sudah sangat parah. Laporan dari Deputi bidang Keluarga Berencana dan Kesehatan Reproduksi Badan Kependudukan bahwa 46\% remaja usia 15-19 sudah melakukan hubungan intim. Selanjutnya, 48-51\% menunjukkan jumlah perempuan yang hamil secara illegal. Senada dengan hal tersebut, ketua Komisi Nasional Perlindungan Anak, Arist Merdeka Sirait mengatakan, sudah ada 1.039 kasus yang melaporkan ke komnas. Lebih dari 50\% adalah kasus pelecehan seksual (Apriani, 2018).

Faktor yang memengaruhi terjadinya perilaku seksual pada remaja adalah perubahan biologis yang terjadi pada masa pubertas dan pengaktifan hormonal, kurangnya peran orang tua melalui komunikasi antara orang tua dan remaja seputar masalah seksual dapat memperkuat munculnya penyimpangan perilaku seksual, pengetahuan remaja yang rendah cenderung lebih sering memunculkan aktivitas seksual dibanadingkan dengan remaja yang berpengetahuan baik, kemudian pengaruh teman sebaya sehingga memunculkan penyimpangan perilaku seksual (Hariyadi \& Ekayanti, 2012).

Adanya faktor yang mempengaruhi perilaku seseorang dalam teori precede procced yang di cetus oleh lawrence green faktor-faktor yang mempengaruhi terjadinya perilaku di kelompokkan menjadi 3 bagian pertama predisposing factor atau faktor predisposisi merupakan faktor mempermudah terjadinya perlakuan dan berasal dari dalam diri individu (diantaranya seperti pengetahuan, sikap, nilai-nilai, tradisi, kepercayaan dan lain-lain). Kedua, enabling factor atau faktor pemungkin merupakan faktor yang memungkinkan individu atau kelompok berperilaku tertentu (diantaranya ketersediaan nya akses pelayanan kesehatan, paparan media informasidan lain-lain). Ketiga reinforcing atau faktor pendorong adalah faktoryang memperkuat terjadinya perilaku (diantaranya dorongan tokoh masyarakat, keluarga, teman sebaya, pemerintah, adanya peraturan, penghargaan dan hukuman).

Pada masa remaja ini peran orang tua bersama guru sangat berpengaruh besar untuk memberikan pengertian tentang makna-makna seksualitas pada remaja yang sesuai dengan nilai-nilai moral yang berlaku di masyarakat. Remaja juga mengalami perubahan moral yaitu dari tingkat pra-konvensional meningkat ketingkat konvensional. Tingkat konvensional yang sedang dilalui oleh remaja ini berarti mereka cenderung menyetujui aturan dan harapan masyarakat . Pada masa-masa perubahan inilah yang menjadikan 
remaja mengalami masa krisis. Di mana individu mulai mengambil keputusan untuk melakukan perubahan atau perbaikan dalam nilai dan tindakan yang pada akhirnya memberi warna tersendiri terhadap kepribadian (Hartono, Sari, Jannah, \& Anonim, n.d.).

Remaja sangat peka terhadap pengaruh nilai baru, terutama mereka yang tidak memiliki pertahanan diri yang baik. Remaja cenderung lebih mudah melakukan penyesuaian dengan arus globalisasi dan arus informasi yang bebas. Masa remaja adalah masa yang penuh gejolak, masa yang penuh dengan berbagai pengenalan akan hal-hal baru sebagai bekal untuk mengisi kehidupan mereka. Pada masa remaja cenderung terjadi perubahan perilaku menyimpang karena adaptasi terhadap nilai-nilai yang datang dari luar sehingga jauh dari norma-norma susila yang dianut masyarakat pada umumnya, seperti pergaulan bebas yang dapat menyebabkan kehamilan yang tidak dikehendaki.

Pemahaman mengenai perilaku seks pada remaja penting di tekankan kepada remaja agar remaja dalam mengambil segala keputusan akan lebih siap dan paham mengenai konsekuensinya terutama yang berhubungan dengan perilaku seksual. Namun demikian realitasnya sulit dibedakan atau dideteksi gejala kejiwaan tersebut dipengaruhi oleh faktor lain diantaranya adalah pengalaman, keyakinan, sarana/fasilitas, sosial budaya dan sebagainya (Indonesia, 2014).

Studi pendahuluan yang dilakukan oleh peneliti di Dusun Para Tujuh Desa Krueng Geukuh kecamatan Dewantara adalah pernah adanya kasus salah seorang remaja SMA yang mengalami kehamilan diluar nikah. Remaja tersebut merupakan siswa yang memerlukan perhatian yang khusus karena kebanyakan siswa berasal dari keluarga kurang mampu dan siswa-siswi yang bermasalah seperti masalah dibidang akademik, orang tua yang broken home, dll. Berdasarkan latar belakang dan fenomena diatas peneliti tertarik untuk melakukan penelitian tentang faktor yang mempengerahui komunikasi dan pola asuh orang tua dengan prerilaku seks di Dusun Para Tujuh Desa Krueng Geukuh Kecamatan Dewantara.

\section{BAHAN DAN METODE}

Penelitian ini dilaksanakan di Dusun Para Tujuh Desa Krueng Geukuh Kecamatan Dewantara Aceh Utara. Populasi dalam penelitian ini adalah seluruh remaja yang usia $14-18$ tahun yang terdapat di Dusun Para Tujuh Desa Krueng Geukuh Kecamatan Dewantara sebanyak 121 orang dan yang menjadi sampel 93 orang.

Penelitian ini merupakan penelitian kuantitatif dengan menggunakan desain korelasi dengan pendekatan pengamatan sewaktu (cross sectional) yang berarti tidak ada perulangan dalam pengambilan data. Desain korelasi bertujuan untuk menganalisis hubungan antara dua variabel atau lebih, tanpa melakukan perubahan, tambahan atau manipulasi terhadap data yang sudah ada (Karolina, Nasution, \& Aritonang, 2013).

Penelitian ini bertujuan untuk mengetahui faktor predisposing, enabling, dan reinforcing pola asuh orang tua dalam mencegah perilaku pergaulan bebas pada remaja.

\section{HASIL PENELITIAN}

Hasil analisa pada lampiran tabel uji chi-square antara pengetahuan dengan perilaku pergaulan bebas, diketahui bahwa nilai probabilitasnya $(0,009)<\operatorname{sig} \alpha \alpha=0,05$. Hasil analisis ini memenuhi kriteria persyaratan hipotesis ada hubungan, sehingga dapat 
Arini Agustina, Idawati

disimpulkan bahwa pengetahuan remaja mempunyai hubungan yang signifikan terhadap pergaulan bebas. Besarnya pengaruh ditunjukkan dengan nilain EXP (B) atau disebut juga Odds Ratio (OR). Variabel pengetahuan dengan OR 0,321, maka remaja yang berpengetahuan kurang berpeluang melakukan pergaulan bebas 3 kali, dari pada remaja yang mempunyai pengetahuan baik.

Hasil analisa pada lampiran tabel uji chi-square antara sikap dengan perilaku pergaulan bebas, diketahui bahwa nilai probabilitasnya $(0,000)<\operatorname{sig} \_\alpha=0,05$. Hasil analisis ini memenuhi kriteria persyaratan hipotesis ada hubungan, sehingga dapat disimpulkan bahwa sikap remaja mempunyai hubungan yang signifikan terhadap pergaulan bebas. Besarnya pengaruh ditunjukkan dengan nilain EXP (B) atau disebut juga Odds Ratio (OR). Variabel sikap dengan OR 10,08, maka remaja yang memiliki sikap negatif berpeluang melakukan pergaulan bebas $10 \mathrm{kali}$, dari pada remaja yang mempunyai sikap positif.

Selanjutnya dari hasil analisa pada lampiran tabel uji chi-square antara kearifan lokal / budaya syariat islam dengan perilaku pergaulan bebas, diketahui bahwa nilai probabilitasnya $(0,001)<\operatorname{sig} \_\alpha=0,05$. Hasil analisis ini memenuhi kriteria persyaratan hipotesis ada hubungan, sehingga dapat disimpulkan bahwa kearifan lokal mempunyai hubungan yang signifikan terhadap pergaulan bebas. Besarnya pengaruh ditunjukkan dengan nilain EXP (B) atau disebut juga Odds Ratio (OR). Variabel kearifan lokal / budaya syariat islam dengan OR 5,33 maka remaja yang memiliki kearifan lokal / budaya syariat islam kurang berpeluang melakukan pergaulan bebas $5 \mathrm{kali}$, dari pada remaja yang baik kearifan lokal/ budaya syariat islamnya.

Hasil analisa pada lampiran tabel uji chi-square antara sosial media dengan perilaku pergaulan bebas, diketahui bahwa nilai probabilitasnya $(0,547)>\operatorname{sig} \_\alpha=0,05$. Hasil analisis ini memenuhi kriteria persyaratan hipotesis tidak ada hubungan, sehingga dapat disimpulkan bahwa sosial media tidak mempunyai hubungan yang signifikan terhadap pergaulan bebas.

Hasil analisa pada lampiran tabel uji chi-square antara keluarga / pola asuh dengan perilaku pergaulan bebas, diketahui bahwa nilai probabilitasnya $(0,846)>\operatorname{sig} \_\alpha=0,05$. Hasil analisis ini memenuhi kriteria persyaratan hipotesis tidak ada hubungan, sehingga dapat disimpulkan bahwa sosial media tidak mempunyai hubungan yang signifikan terhadap pergaulan bebas.

Hasil analisa pada lampiran tabel uji chi-square antara teman sebaya dengan perilaku pergaulan bebas, diketahui bahwa nilai probabilitasnya $(0,035)<\operatorname{sig} \_\alpha=0,05$. Hasil analisis ini memenuhi kriteria persyaratan hipotesis ada hubungan, sehingga dapat disimpulkan bahwa teman sebaya mempunyai hubungan yang signifikan terhadap pergaulan bebas. Besarnya pengaruh ditunjukkan dengan nilai EXP (B) atau disebut juga Odds Ratio (OR). Variabel teman sebaya dengan OR 0,214, maka remaja yang berpengaruh dengan teman sebaya melakukan pergaulan bebas, dari remaja yang tidak terpengaruh oleh teman sebaya.

Pada tabel variabel in the equation di atas: variabel pengetahuan dan sikap yang nilai $\mathrm{P}$ value (sig) < 0,05, artinya variabel sikap (X1) dan kearifan lokal (X2) mempunyai pengaruh yang signifikan terhadap Y di dalam model. X1 atau sikap mempunyai nilai signifikan 0,000 < 0,05 sehingga menolak Ho atau yang berarti sikap memberi pengaruh signifikan terhadap 
pergaulan bebas. X2 atau kearifan lokal mempunyai nilai signifikan 0,006 $<0,05$ sehingga menolak Ho atau yang berarti kearifan lokal memberi pengaruh signifikan terhadap pergaulan bebas. Uji signifikan parameter dapat pula dilakukan menggunakan niai interval konfidensi 95\%. Dengan lower sebesar 2,743 dan upper 30.237, maka dapat disimpulkan bahwa sikap berpengaruh nyata terhadap pergaulan bebas. Besarnya pengaruh ditunjukkan dengan nilai EXP (B) atau disebut ODDS RATIO (OR). Variabel sikap dengan OR 9,107, maka orang yang bersikap negative lebih beresiko melakukan pergaulan bebas sebanyak 9,107 kali di bandingkan dengan orang yang berperilaku positif, maka sikap mempunyai hubungan signifikan dengan pergaulan bebas.

\section{PEMBAHASAN}

\section{Hubungan Pengetahuan Dengan Perilaku Pergaulan Bebas}

Hasil penelitian diatas sejalan dengan pendapat Notoatmodjo bahwa salah satu faktor yang menentukan perilaku tentang kesehatan seseorang adalah pengetahuan, semakin tinggi pengetahuan seseorang, maka semakin dapat ia memanfaatkan kemampuan tersebut (Gamelia et al., 2015).

Selain itu, ada beberapa faktor yang mempengaruhi perilaku pergaulan bebas. Pertama, industri pornografi. Luasnya peredaran materi pornografi memberi pengaruh yang sangat besar terhadap pembentukan pola perilaku seks remaja. Kedua, pengetahuan remaja tentang dampak dari pergaulan bebas. Sehingga dapat menimbulkan dampak pada pola perilaku remaja yang tidak sehat dan membahayakan. Ketiga, pengalaman masa remaja-remaja. Dari hasil penelitian menunjukkan bahwa remaja yang mengalami pengalaman buruk akan mudah terjebak ke dalam aktivitas-aktivitas negative seperti taruan, mabuk-mabukan, perilaku seks bebas dan lain-lain. Keempat, pembinaan religius. Remaja yang memiliki kehidupan religius yang baik, lebih mampu berkata 'tidak' terhadap godaan pergaulan bebas dibandingkan mereka yang tidak memperhatikan kehidupan religious (Hardika, 2017).

Menurut asumsi peneliti adanya hubungan variabel pengetahuan dengan pergaulan bebas karena kurangnya pengetahuan remaja terhadap dampak dari pergaulan bebas. Hal ini yang menyebabkan, banyaknya keinginan remaja untuk mencoba hal-hal yang baru dan tidak dapat mengontrol diri dalam hal tersebut, karena awal mula perilaku pergaulan bebas di mulai dari pacaran, perngaruh teman sebaya, update gaya kekinian, kewajaran dalam bersikap, dan tidak peduli terhadap norma-norma yang berlaku. Hal inilah yang mengakibatkan meningkatnya angka kasus pergaulan bebas, rasa nikmatan sesaat banyak membuat remaja salah dalam menetukan sikap.

\section{Hubungan Sikap Dengan Perilaku Pergaulan Bebas}

Hasil tersebut diatas sejalan dengan pendapat Notoatmodjo bahwa salah satu faktor yang menentukan perilaku tentang kesehatan seseorang adalah pengetahuan dan sikap, semakin tinggi pengetahuan dan sikap mendukung seseorang, maka semakin dapat ia memanfaatkan kemampuan tersebut. Pengetahuan tentang pergaulan bebas yang kurang didukung dengan sikap yang negatif. Pengetahuan tentang pergaulan bebas yang baik di 
Arini Agustina, Idawati

dukung dengan sikap yang positif pula akan menyebabkan seseorang mampu menghindari perilaku pergaulan bebas (Obstetri et al., 2017).

Penelitian ini diperoleh dengan observasi langsung di kawasan pendidikan seperti sekolah dengan menghasilkan adanya pengaruh sikap remaja terhadap seks menyangkut moralitas yang dimilki oleh remaja itu sendiri. Pada umumnya remaja mempunyai sikap terhadap perilaku seks bebas yang tergolong tidak setuju terhadap perilaku seks bebas akan tetapi pada masa remaja, banyak peran yang seharusnya wajib berpartisipasi dalam pendidikan seks apalagi pada masa remaja butuh bimbingan ekstra karena emosional dan pencarian jati diri sehingga remaja mudah terpengaruh terhadap pergaulan khususnya seks bebas ini. Berdasarkan penelitian, peneliti mengajukan beberapa saran : perlu adanya pembinaan nilai-nilai moral sejak dini tanpa menggunakan larangan atau hukuman, namun dengan cara remaja selalu diajak untuk berfikir, yang selalu menerangkan mengapa suatu perbuatan dilarang atau diperintahkan, apa maksudnya dan apa motivasinya, sehingga mereka akan menjadi orang yang selalu terbuka terhadap sesuatu yang baru; termasuk pergaulan seks bebas dan yang akan bertindak berdasarkan tanggung jawab yang nyata, semakin baik tingkat penalaran moral, maka semakin negatif sikap remaja terhadap perilaku seks bebas.

Menurut asumsi peneliti, adanya hubungan variabel sikap dengan pergaulan bebas karena pada usia remaja mereka mulai ingin mencoba hal yang baru dengan tingkat emosional yang tinggi. Hal tersebut terjerumus terhadap pergaulan bebas seperti tauran, menggunakan narkotika, dan ada pula keinginan mereka untuk melakukan seks bebas yang bermula dari berpacaran. Sehingga mereka dipandang memerlukan informasi yang bertanggung jawab mengenai pendidikan seksualitas. Atas dasar pertimbangan dari pengamatan ini, banyak remaja dipandang perlu mendapatkan tambahan wawasan yang lebih detail tentang hubungan antara laki-laki dengan perempuan, dan mengenai bagaimana pergaulan atau pacaran yang sehat. Kebanyakan remaja tidak berani menolak kalau pacarnya ingin berbuat seks bebas, sehingga mereka melakukan hubungan seks yang bebas. Semua ini dapat terjadi karena kepribadian dan tingkat penalaran moral siswa yang kurang baik. Keberhasilan perkembangan penalaran moral remaja di masyarakat ikut menentukan keberhasilan remaja dalam menentukan pola pergaulannya di masyarakat.

\section{Hubungan kearifan lokal/budaya syariat islam dengan perilaku mmnpergaulan bebas}

Tingkat kenakalan remaja seperti pergaulan bebas, minuman keras, narkoba memang sering terjadi, namun kenakalan seperti pencurian, merokok, berjudi jarang dilakukan remaja walaupun ada yang melakukannya. Diantara faktor penyebab terjadinya pergaulan bebas remaja muslim adalah aqidah yang tipis dan dangkalnya pengetahuan tentang ajaran agama masing-masing, pergaulan, dan media masa (HS, Zuska, \& Rifai, 2019). Salah satu Solusi untuk mengurangi pergaulan bebas remaja adalah bimbingan keluarga / pola asuh dan pemerintah juga harus bisa bekerja sama dengan tokoh-tokoh agama yang ada di setiap desa.

Menurut asumsi peneliti, adanya hubungan variabel dengan kearifan lokal / budaya syariat islam dengan pergaulan bebas karena banyak remaja yang tidak menaati norma agama. Hal ini mungkin menjadi sorotan di kalangan masyarakat luar, Aceh sebagai 
daerah otonom yang sangat menengakkan syariat islam tetapi masih adanya pergaulan bebas pada remaja. Jika di kaji lebih lebih mendalam, penegakan syariat islam tidak semata karena aturan/ qanun, akan tetapi kembali lagi terhadap individu taat atau tidak dalam menjalankan aturan/qanun tersebut. Terutama pada kalangan remaja yang berkaiatan erat dengan pergaulan bebas yang menjadi permasalahan yang paling besar dimata tokoh-tokoh agama dan masyarakat pada masa sekarang ada beberapa poin yang sangat membuat masyarakat menjadi terganggu diantaranya: pergaulan bebas, narkoba, minuman keras, pencurian, merokok, berjudi, dan hal-hal lainnya yang bersifat negatif.

\section{Hubungan Sosial media dengan perilaku pergaulan bebas}

Selain itu, dampak yang paling berbahaya pada remaja-remaja yang tanpa sengaja mendapatkan informasi dari jejaring sosial seperti kiriman link (jaringan) konten porno. Efek keingintahuan remaja-remaja sangat besar apalagi melihat hal yang baru. Oleh karena keterbatasan waktu dan aktivitas kerja keluarga / pola asuh maka peran untuk mengontrol aktivitas internet remaja, mengarah, dan memberikan evaluasi terhadap apa saja yang dilakukan remaja di internet harus kontinyu (Notoatmodjo, 2012).

Menurut asumsi peneliti, tidak adanya hubungan variabel sosial media dengan pergaulan bebas karena beberapa alasan seperti terbatasnya jumlah kuota atau kapastitas paket internet pada handphone remaja dalam mengakses, hal ini disebabkan oleh faktor ekonomi dan status remaja sebagai pelajar. Remaja yang berumur 14-18 tahun uang jajan sering di batasi oleh orang tua, mereka hanya diberikan uang jajan sesuai dengan kebutuhan sehari-hari, kecuali bagi remaja yang mau menyisihkan sedikit uang jajannya untuk ke warnet dan itupun dalam jumlah nominal yang sangat sedikit, kecuali apabila remaja tersebut mempunyai lingkungan pertemanan dengan orang dewasa yang memberikan efek negatif, seperti memperlihatkan memperlihatkan gambar-gambar pornografi yang ada pada handphone orang dewasa tersebut

\section{Hubungan keluarga / pola asuh dengan perilaku pergaulan bebas}

Mereka mencintai dan menerima, tetapi juga menuntut perilaku yang baik dan memiliki keinginan untuk menjatuhkan hukuman yang bijaksana dan terbatas ketika hal tersebut dibutuhkan. Tindakan verbal memberi dan menerima, orang tua bersikap hangat dan penyayang kepada remaja. Menunjukkan dukungan dan kesenangan kepada remaja. Remaja merasa aman ketika mengetahui bahwa mereka dicintai dan dibimbing secara hangat. Serta orang tua mengajarkan disiplin kepada remaja agar remaja dapat mengeksplorasi lingkungan dan memperoleh kemampuan interpersonal. Remaja yang memiliki orang tua yang otoritatif bersifat ceria, bisa mengendalikan diri, berorientasi pada prestasi, mempertahankan hubungan dengan teman sebaya, bekerja sama dengan orang dewasa, dapat mengatasi stres dengan baik (Muliati, Ismanto, \& Malara, 2014).

Menurut asumsi peneliti tidak ada hubungan variabel pola asuh keluarga dengan pergaulan bebas. Hal ini berdasarkan pengkajian peneliti sebelumnya, mayoritas pola asuh remaja demokrasi. Pada pola asuh ini memprioritaskan kepentingan remaja. Orang tua dengan pola asuh ini bersikap rasional, selalu mendasari tindakannya pada rasio atau pemikiran-pemikiran. Bersikap realistis terhadap kemampuan remaja, tidak berharap yang 
Arini Agustina, Idawati

berlebihan yang melampaui kemampuan remaja. Memberikan kebebasan kepada remaja untuk memilih dan melakukan suatu tindakan, dan pendekatannya kepada remaja bersifat hangat. Mendorong remaja untuk mandiri namun menerapkan batas dan kendali pada tindakan mereka. Orang tua memiliki keyakinan diri akan kemampuan membimbing remaja-remaja mereka, tetapi juga orang tua menghormati independensi keputusan, pendapat, dan kepribadian remaja.

\section{Hubungan teman sebaya dengan perilaku pergaulan bebas}

Teman sebaya merupakan lingkungan sosial pertama tempat remaja belajar untuk hidup bersama dengan orang lain yang bukan anggota keluarganya. Bersama teman sebaya remaja belajar untuk saling menghargai, bertoleransi, dan bertanggung jawab. Teman sebaya merupakan lingkungan sosial tempat berinteraksi dimana anggotanya memiliki kesamaan usia, selain itu anggotanya juga memiliki persamaan sekolah, hobi, minat, status sosial, ekonomi, dan sebagainya (Dalam, Pemeriksaan, \& Care, 2012).

Remaja sangat terbuka terhadap kelompok teman sebaya. Mereka melakukan diskusi tentang roman, falsafah hidup rekreasi, perhiasan, pakaian, sampai berjam-jam Pengaruh teman sebaya menjadi suatu jalinan ikatan yang sangat kuat. Teman/sahabat sebaya adalah teman yang berada pada usia yang sama dan diantara mereka biasanya terjalin keakraban. Peranan teman/sahabat sebaya pada remaja sangat besar dalam kehidupan remaja seharihari. Remaja lebih banyak berada diluar rumah bersama teman-teman sebaya sebagai kelompok, pengaruh teman teman sebaya pada sikap, pembicaraan, minat, dan perilaku lebih besar dari pengaruh keluarga (Dengan, Pasien, Pada, \& Hamil, 2017).

Menurut asumsi peneliti, adanya hubungan variabel teman sebaya dengan pergaulan bebas. Perilaku teman sebaya dalam kelompok menjadi acuan atau norma tingkah laku yang diharapkan dalam kelompok. Salah satu bentuk pergaulan bebas yaitu gaya berpacaran teman sebaya menjadi model atau acuan yang digunakan seseorang remaja dalam pacaran. Teman biasa melakukan ciuman dengan pacarnya, maka dibenarkan kalau dia juga berciuman. Remaja cenderung mengembangkan norma sendiri yang bertentangan dengan norma umum yang berlaku.

\section{KESIMPULAN}

Berdasarkan hasil dan pembahasan yang telah dipaparkan pada bab sebelumnya dapat diambil beberapa kesimpulan untuk penelitian ini yaitu: ada hubungan pengetahuan dengan pergaulan bebas. Variabel pengetahuan dengan OR 3,11, maka remaja yang memiliki berpengetahuan kurang berpeluang pernah melakukan pergaulan bebas 3 kali, dari pada remaja yang mempunyai pengetahuan baik, ada hubungan sikap dengan pergaulan bebas. Variabel sikap dengan OR 10,08, maka remaja yang memiliki sikap negative berpeluang pernah melakukan pergaulan bebas $10 \mathrm{kali}$, dari pada remaja yang mempunyai bersikap positif., ada hubungan Kearifan lokal / budaya syariat islam dengan pergaulan bebas. Variabel kearifan lokal/ budaya syariat islam dengan OR 5,33, maka remaja yang memiliki kearifan lokal / budaya syariat islam kurang berpeluang pernah melakukan pergaulan bebas 5 kali, dari pada remaja yang baik kearifan lokal/ budaya syariat islam, tidak ada hubungan sosial media dengan pergaulan bebas, ada hubungan teman sebaya dengan pergaulan bebas. Variabel teman sebaya dengan OR 0,00, maka 
remaja yang berpengaruh dengan teman sebaya berpeluang melakukan pergaulan bebas, dari remaja yang tidak terpengaruh oleh teman sebaya, dan variabel sikap dominan memengaruhi pergaulan bebas

\section{SARAN}

Disarankan kepada remaja agar membentengi diri dari dampak pergaulan bebas seperti menahan hasrat untuk melakukan hal-hal yang negatif, memenuhi kesibukan diri dengan hal-hal yang positif dan meningkatkan ilmu tentang agama.

\section{UCAPAN TERIMA KASIH}

Pada kesempatan ini, saya mengucapkan terima kasih kepada kepala desa Krueng Geukuh Kecamatan Dewantara yang relah memberikan izin untuk melaksanakan penelitian ini dan kepada remaja yang telah bersedia menjadi responden sehingga kegiatan ini dapat berjalan lancar

\section{DAFTAR PUSTAKA}

Apriani, L. (2018). HUBUNGAN KARAKTERISTIK IBU, PELAKSANAAN KELUARGA SADAR GIZI (KADARZI) DAN PERILAKU HIDUP BERSIH SEHAT (PHBS) DENGAN KEJADIAN STUNTING (Studi kasus pada baduta 6-23 bulan di Wilayah Kerja Puskesmas Pucang Sawit Kota Surakarta). Jurnal Kesehatan Masyarakat (e-Journal), 6(4), 198-205.

Dalam, H., Pemeriksaan, M., \& Care, A. (2012). Faktor-faktor yang mempengaruhi ibu hamil dalam melakukan pemeriksaan antenatal care.

Dengan, B., Pasien, K., Pada, B., \& Hamil, I. B. U. (2017). Hubungan pelaksanaan antenatal care (anc) oleh bidan dengan kepuasan pasien bpjs pada ibu hamil di poli kia puskesmas limpung batang.

Gamelia, E., Sistiarani, C., Masfiah, S., Kesehatan, J., Fakultas, M., Universitas, I. K., \& Soedirman, J. (2015). Determinant of Mother' s Prenatal Care Behaviour, 109-114.

Hardika, M. D. (2017). HUBUNGAN PELAKSANAAN KELUARGA SADAR GIZI (KADARZI) DENGAN STATUS GIZI ANAK 1-4 TAHUN. Bidan Prada: Jurnal Publikasi Kebidanan Akbid YLPP Purwokerto.

Hariyadi, D., \& Ekayanti, I. (2012). Analisis pengaruh perilaku keluarga sadar gizi terhadap stunting di propinsi kalimantan barat. Teknologi Dan Kejuruan, 34(1).

Hartono, M., Sari, Y. S., Jannah, M., \& Anonim, T. (n.d.). RELATED KNOWLEDGE THIRD TRIMESTER PREGNANT WITH COMPLIANCE IN THE ANTENATAL CARE ( ANC ) IN HEALTH INSPECTION KUSUMABANGSA COMMUNITY HEALTH CENTERS.

HS, N., Zuska, F., \& Rifai, A. (2019). Perilaku Seks Pranikah pada Remaja Kota Juang Bireun. Serambi Saintia: Jurnal Sains Dan Aplikasi. https://doi.org/10.32672/jss.v7i1.990

Indonesia, K. K. R. (2014). InfoDATIN: Pusat Data dan Informasi Kementerian Kesehatan RI. Jakarta: Kementerian Kesehatan Republik Indonesia.

Karolina, E., Nasution, E., \& Aritonang, E. Y. (2013). HUBUNGAN PERILAKU 
Arini Agustina, Idawati

KADARZI DENGAN STATUS GIZI BALITAUSIA 12-59 BULAN DI WILAYAH KERJA PUSKESMAS BLANGKEJEREN KECAMATAN BLANGKEJEREN KABUPATEN GAYO LUES TAHUN 2012. Gizi, Kesehatan Reproduksi Dan Epidemiologi, 2(2).

Muliati, D. D., Ismanto, A. Y., \& Malara, R. (2014). Hubungan Keluarga Sadar Gizi Dengan Status Gizi Balita Di Desa Mopuya Selatan Kecamatan Dumoga Utara Kabupaten Bolaang Mongondow. JURNAL KEPERAWATAN, 2(2).

Notoatmodjo, S. (2012). Promosi kesehatan dan perilaku kesehatan. Jakarta: Rineka Cipta, 45-62.

Obstetri, B., Kedokteran, F., Lampung, U., Ilmu, B., Keluarga, K., \& Kedokteran, F. (2017). Faktor-faktor yang Memengaruhi Kunjungan Antenatal Care ( ANC ) Ibu Hamil Factors Affecting The Antenatal Care ( ANC) Visits on Pregnant Women, 7(November), 72-76. 